\title{
The Effectiveness Test of Oil Phase Ointment Containing Snakehead Fish (Channa striata) Extract on Open Stage II Acute Wounded Wistar Strain Male Rats
}

\author{
Uji Efektivitas Salep Fase Minyak Ekstrak Ikan Gabus (Channa striata) \\ pada Tikus Jantan Galur Wistar Yang Diberi Luka Akut \\ Stadium II Terbuka
}

\author{
Fransisca Daisa*, Mohamad Andrie, Wintari Taurina \\ Program Studi Farmasi, Fakultas Kedokteran Universitas Tanjungpura Pontianak
}

\begin{abstract}
The snakehead (Channa striata) contained fatty acids omega-3 and omega-6 are useful as nutrients in accelerating the wound healing process. This study aims to determine the effectiveness of the oil phase extract ointment snakehead in the healing of acute wounds open stage II. Testing the effectiveness of wound healing using 6 groups: normal, gel bioplacenton (positive control), ointment base (negative control), ointments snakehead extract oil phase concentration of 10; 20 and 40\% of the 4 rats with acute wounds open stage II and observation until day 16 injury. The area of the wound was measured with the image J program Macbiophotonic, calculated\% healing power, and AUC values. A statistical test to the total AUC values per rat with SPSS for Windows 22.0 program using One Way ANOVA and Post-hoc LSD test. The results showed a significant difference in the negative group with ointment concentration of $20 \%(p<0.05)$. The treatment group phase ointment fish oil extract is effective for wound healing is best to have a concentration of $20 \%$ for percentage of wound healing power of $97.157 \%$ and the average AUC value of $865.683 \%$ of the day.

Keyword : Ointment, fatty acid, snakehead oil, wound healing, Macbiophotonic image J
\end{abstract}

\begin{abstract}
ABSTRAK
Ikan gabus (Channa striata) memiliki kandungan asam lemak omega-3 dan omega-6 yang bermanfaat sebagai nutrisi dalam mempercepat proses penyembuhan luka. Penelitian ini bertujuan untuk mengetahui efektivitas salep fase minyak ekstrak ikan gabus dalam penyembuhan luka akut stadium II terbuka. Pengujian efektivitas penyembuhan luka menggunakan 6 kelompok yaitu kelompok normal, gel bioplacenton (kontrol positif), basis salep (kontrol negatif), salep fase minyak ekstrak ikan gabus konsentrasi 10; 20 dan 40\% terhadap 4 ekor tikus dengan luka akut stadium II terbuka dan pengamatan sampai hari ke16 perlukaan. Luas area luka diukur dengan program Macbiophotonic image J, dihitung \% daya penyembuhan dan nilai AUC. Uji statistik terhadap rata-rata nilai AUC per tikus dengan program SPSS for Windows 22.0 menggunakan One Way ANOVA dan Post hoc Test-LSD. Hasil peneitian menunjukkan adanya perbedaan signifikan kelompok negatif dengan salep konsentrasi $20 \%(p<0,05)$. Kelompok perlakuan salep fase minyak ekstrak ikan gabus yang memiliki efektivitas penyembuhan luka terbaik adalah konsentrasi $20 \%$ dengan persentase daya penyembuhan luka sebesar 97,157\% dan nilai rata-rata AUC sebesar 865,683 $\%$.hari.
\end{abstract}

Kata Kunci : Salep, fase minyak ekstrak, ikan gabus, penyembuhan luka, Macbiophotonic Image J

\section{PENDAHULUAN}

Sebuah kerusakan pada jaringan yang mengganggu proses selular normal tubuh khususnya pada kulit disebut luka (Mansjoer, 2000). Penyembuhan merupakan proses alami tubuh dalam regenerasi kerusakan jaringan kulit dan epidermal namun tingkat penyembuhannya sangat lambat dan memungkinkan adanya infeksi

Correspondence author: Fransisca Daisa

Email : fransisca_daisa@yahoo.com mikroba (Sabale et al., 2012). Prinsip dasar dalam mengoptimalkan penyembuhan luka yaitu dengan meminimalkan kerusakan jaringan dan menyediakan perfusi jaringan serta oksigenasi yang cukup, pemberian nutrisi yang tepat dengan kondisi lingkungan penyembuhan luka yang lembab untuk mengembalikan kontinuitas anatomi dan fungsi jaringan yang rusak dalam waktu singkat (Gadekar et al., 2012).

Pengobatan secara tradisional sebagai alternatif untuk menyembuhkan luka banyak 
digunakan karena tidak menghasilkan efek samping seperti pada pengobatan secara kimiawi. Selain itu, masyarakat umumnya beranggapan bahwa penggunaan obat tradisional lebih aman dibandingkan dengan obat sintesis (Anton, 1989). Salah satu sumber bahan obat dari alam adalah ikan. Ikan gabus merupakan ikan konsumsi yang dimanfaatkan untuk penyembuhan luka. Di dalam dunia kedokteran, ikan gabus digunakan untuk menyembuhkan luka pasca operasi dan luka bakar dengan mengambil ekstrak minyak ikan tersebut (Saleh et al., 1985).

Asam lemak yang terdapat dalam minyak ikan gabus, yaitu omega-3 dan omega- 6 berperan dalam proses penyembuhan luka. Asam lemak berperan dalam sistem kekebalan tubuh yaitu dalam proses pembentukan kolagen dan jaringan epitel pada luka. Pembentukan kembali jaringan epitel dalam penyembuhan luka juga dipercepat oleh pengaruh pengaplikasian secara topikal dengan manfaat pembersihan luka secara cepat hingga meminimalkan bekas luka (Naveh et al., 2011; Shafri and Mat 2012).

Salep minyak ikan gabus pada konsentrasi $10 \%$ dan gel ekstrak ikan gabus pada konsentrasi 5\% dalam penelitian sebelumnya menunjukkan bahwa pemberian sediaan secara topikal tersebut dapat memberikan efek penyembuhan luka sayat. Salep minyak ikan gabus yang telah dioptimasi dapat menyembuhkan luka sayat selama 7 hari, sedangkan gel ekstrak ikan gabus memberikan efektivitas penyembuhan luka sayat terbaik pada hari ke-9 (Sinambela, 2012; Gusdi, 2012).

Konsentrasi obat menjadi faktor penting dalam mempengaruhi absorpsi perkutan. Jumlah obat yang diabsorpsi secara perkutan perunit luas permukaan akan bertambah sebanding dengan bertambahnya konsentrasi obat dalam suatu pembawa Ansel, 1989. Dengan meningkatnya konsentrasi obat diharapkan dapat mempercepat proses penyembuhan luka. Berdasarkan hal tersebut maka pada penelitian ini akan dilakukan uji efektivitas salep fase minyak ekstrak ikan gabus dengan konsentrasi $10 \%$, 20\%, dan $40 \%$ sebagai penyembuhan luka yang terbaik.

\section{METODOLOGI}

\section{Bahan dan alat}

Alat yang digunakan dalam penelitian ini antara lain alat press hidraulik, alat sentrifugasi (PLC-05 series), gelas ukur 500mL (Pyrex), tabung reaksi (Pyrex), timbangan analitik, mortir, stamper, cetakan luka, gunting bedah, cawan petri, beban $1 \mathrm{~g}, 3 \mathrm{~g}, 5 \mathrm{~g}, 50 \mathrm{~g}$, dan gelas objek,. Bahan yang digunakan adalah fase minyak ekstrak ikan gabus.

\section{Hewan Uji}

Penelitian ini menggunakan hewan uji yaitu tikus putih jantan (Rattus norvegicus) galur Wistar dengan disertai ethical clearance (Lampiran).

\section{Pengumpulan dan Pengolahan Simplisia Hewan}

Simplisia hewan berupa ikan gabus yang diperoleh dan dikumpulkan dari pedagang ikan yang terletak di Desa Padang Tikar, Kecamatan Batu Ampar, Kabupaten Kuburaya, Kalimantan Barat. Sebanyak $\pm 8 \mathrm{~kg}$ daging ikan gabus dikukus dalam panci selama \pm 30 menit pada kompor gas dengan suhu $65-70^{\circ} \mathrm{C}$, kemudian daging ikan gabus ini dibungkus dengan serbet dan dimasukkan ke dalam alat press hidraulik, setelah itu dilakukan pengepresan untuk mengambil ekstrak yang mengandung fase minyak ekstrak ikan gabus.

Ekstrak ikan gabus yang telah didapat di masukkan ke dalam tabung reaksi dan ditutup dengan clean pack, kemudian ekstrak di sentrifugasi selama 60 menit pada kecepatan $6000 \mathrm{rpm}$. Setelah itu ekstrak ikan gabus yang mengandung minyak dipisahkan menggunakan spuit lalu fase minyak ekstrak ikan gabus tersebut disimpan di dalam wadah dan ditutup dengan alumunium foil dan clean pack (Sinambela, 2012).

\section{Formulasi Salep Fase Minyak Ekstrak Ikan Gabus}

Salep dibuat ke dalam tiga formulasi dengan variasi konsentrasi zat aktif 10, 20 dan 40\% (Tabel I).

Tabel I. Formulasi salep fase minyak ekstrak ikan gabus

\begin{tabular}{lccc}
\hline \multicolumn{1}{c}{ Bahan } & $\mathbf{1 0 \%}$ & $\mathbf{2 0 \%}$ & $\mathbf{4 0 \%}$ \\
\hline Fase minyak ekstrak ikan & 2 & 4 & 8 \\
gabus (g) & 0,02 & 0,02 & 0,02 \\
Antioksidan & 0,24 & 0,24 & 0,24 \\
Zat pengawet & \multicolumn{3}{c}{ Ad 20 } \\
$\begin{array}{l}\text { Adeps lanae (g) dan vaselin } \\
\text { flavum (g) }\end{array}$ & \multicolumn{3}{c}{. } \\
\hline
\end{tabular}

\section{Pembuatan Salep Fase Minyak Ekstrak Ikan Gabus}

Pembuatan salep dimulai dengan penimbangan bahan-bahan yang digunakan. Kemudian digerus dengan antioksidan, sedikit basis, dan zat aktif hingga homogen. Campuran basis kemudian digerus, ditambahkan dengan larutan pengawet lalu diaduk hingga homogen. Kedua campuran dicampurkan hingga homogen.. Hasilnya dimasukkan ke dalam pot salep dan dilakukan evaluasi sediaan (Andrie, 2015). 


\section{Evaluasi Sediaan Salep Fase Minyak Ekstrak Ikan Gabus Uji Organoleptis}

Pengujian organoleptis sediaan dilakukan dengan pancaindera untuk mendeskripsikan bentuk atau konsistensi (misalnya padat, kental, cair), warna (misalnya kuning, coklat) dan bau (misalnya aromatik, tidak berbau). Pemeriksaan terhadap organoleptik yang dilakukan meliputi tekstur, warna dan bau yang diamati secara visual (Andrie, 2015).

\section{Uji Daya Sebar}

Penyebaran salep diartikan sebagai kemampuan penyebarannya pada kulit. Pemeriksaan daya sebar dilakukan dengan cara sebagai berikut. Salep hasil formulasi sebanyak $0,5 \mathrm{~g}$ diletakkan ditengah antara dua petri di atas kertas grafik, dibiarkan selama 60 detik dan dihitung luas daerah yang diberi sediaan. Bersihkan petri dari sediaan dan ulangi langkah di atas kemudian diberi beban $1 \mathrm{~g}$ lalu dibiarkan selama 60 detik, pertambahan luas yang diberikan oleh sediaan dapat dihitung dengan menambahkan beban menjadi $3 g$ dan $5 g$ (Andrie, 2015).

\section{Uji Daya Lekat}

Uji daya lekat dilakukan untuk mengetahui kemampuan salep melekat pada kulit. Pemeriksaan daya lekat dilakukan dengan meletakkan salep sebanyak $0,05 \mathrm{~g}$ di atas gelas objek yang telah diketahui luasnya dan gelas objek yang lain diletakkan di atas salep tersebut. Kemudian ditekan dengan beban $50 \mathrm{~g}$ selama 30 detik. Dipasang gelas objek pada alat tes, beban seberat $16 \mathrm{~g}$ kemudian dilepaskan dan dicatat waktunya hingga kedua gelas objek ini terlepas (Andrie, 2015).

\section{Pengelompokkan Hewan Uji}

Sebanyak 24 ekor tikus putih jantan galur wistar dibagi menjadi 6 kelompok sebanyak masing-masing 4 ekor yaitu kelompok normal yaitu tidak diberi perlakuan terhadap luka, kelompok kontrol negatif yaitu diberi basis salep tanpa zat aktif 2 kali sehari sampai hari ke 16, kelompok positif yaitu diberi gel bioplacenton 2 kali sehari sampai hari ke 16, kelompok perlakuan salep $10 \%$ yaitu diberi salep konsentrasi $10 \%$ sebanyak 2 kali sehari sampai hari ke 16, kelompok perlakuan salep 20\% yaitu diberi salep konsentrasi $20 \%$ sebanyak 2 kali sehari sampai hari ke 16, kelompok perlakuan salep 40\% diberi salep konsentrasi 40\% sebanyak 2 kali sehari sampai hari ke 16.
Pengujian Salep Fase Minyak Ekstrak Ikan Gabus Terhadap Hewan Uji

Bulu punggung dicukur diameter $4 \mathrm{~cm}$ dan dibersihkan dengan alkohol 70\%. Tikus dianestesi menggunakan eter $10 \%$ melalui jalur inhalasi. Luka dibuat dengan dipotong bagian kulit sesuai cetakan yang telah disiapkan dengan diameter 2 $\mathrm{cm}$ dan kedalaman luka $2 \mathrm{~mm}$ dan potongan kulit diangkat dari punggung tikus (Morton et al., 1992). Perlukaan dilakukan sama pada setiap kelompok hewan uji.

\section{Pengamatan Luas Area Luka}

Dilakukan pengamatan pada luka di hari ke-2 sampai hari ke-16. Luka di foto dan dikuantifikasi dengan menggunakan parameter $\%$ daya penyembuhan. Kuantifikasi dibantu program komputer yaitu Macbiophotonics Image J sampai diperoleh hasil pengukuran luas area luka dengan satuan $\mathrm{mm}^{2}$.

\section{Analisis Data}

Analisis data dilakukan secara statistik dengan metode ANOVA (Analysis of Variant) yang dibantu dengan program SPSS 22.0 for windows.

\section{HASIL DAN PEMBAHASAN}

\section{Hasil Ekstraksi Daging Ikan Gabus}

Hasil dari ekstrak terdiri atas 3 lapisan yaitu fase minyak berada di permukaan berwarna kuning terang dan berbau khas minyak, fase air berada di tengah berwarna kuning pucat dan berbau amis khas ikan, dan zat pengotor berada di bagian bawah tabung reaksi.

\section{Hasil Evaluasi Uji Sediaan Salep Fase Minyak Ekstrak Ikan Gabus \\ Hasil Uji Organoleptis \\ Pengamatan organoleptis menunjukkan} bahwa sediaan salep berwarna kuning, mempunyai konsistensi yang homogen, bau berlemak dan khas.

\section{Hasil Uji Daya Sebar}

Pengujian daya sebar sediaan salep fase minyak ekstrak ikan gabus dilakukan pada cawan petri yang dapat menggambarkan penyebaran salep pada kulit yang diobati (Gambar 1). Semakin luas penyebaran sediaan pada permukaan kulit maka absorpsi dari bahan obat yang terkandung akan semakin meningkat (Gitarja, 2008). Berdasarkan hasil pengamatan, salep konsentrasi $40 \%$ memiliki daya sebar yang paling besar. 
Grafik Hasil Uji Daya Sebar

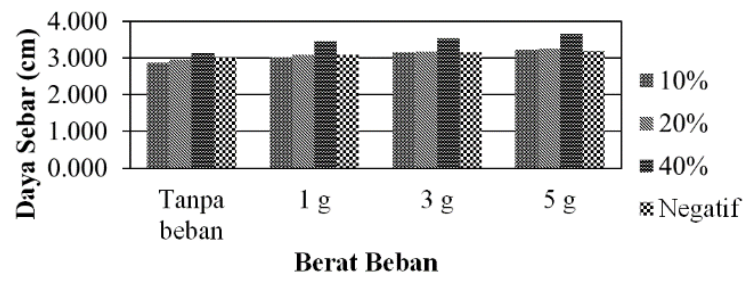

Gambar 1. Grafik Hasil Uji Daya Sebar

\section{Hasil Uji Daya Lekat}

Uji daya lekat dilakukan pada kaca objek untuk menggambarkan waktu yang diperlukan sediaan salep fase minyak ekstrak ikan gabus menempel dengan permukaan kulit. Semakin lama kemampuan melekat pada kulit, maka efek terapi yang diberikan relatif lebih lama (Ansel, 1989). Berdasarkan hasil pengamatan, daya lekat paling besar yaitu salep konsentrasi $10 \%$.

Grafik Hasil Uji Daya Lekat

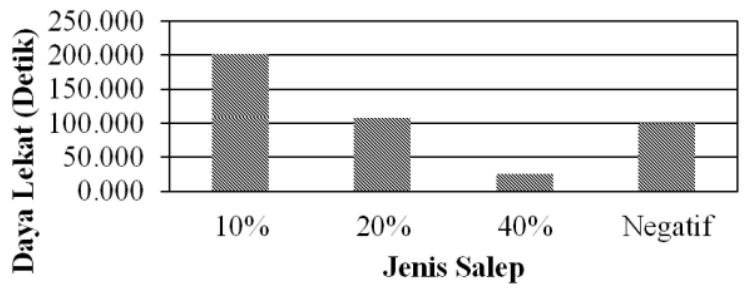

Gambar 2. Grafik Hasil Uji Daya Lekat

\section{Hasil Uji Efektivitas Salep Fase Minyak Ekstrak Ikan Gabus}

Uji analisis statistik dilakukan terhadap nilai AUC total tiap tikus per kelompok. Uji normalitas dengan Shapiro-Wilk menunjukkan bahwa data terdistribusi normal dengan nilai signifikansi lebih dari 0,05 ( $p>0,05)$. Selanjutnya dilakukan uji Homogenity of Variances yang menunjukkan bahwa data homogen dengan nilai signifikansi lebih dari $0,05(\mathrm{p}>0,05)$. Pengujian dilanjutkan dengan uji parametrik yaitu One Way ANOVA karena telah memenuhi syarat uji terdistribusi normal dan homogenitas. Hasil uji menunjukkan bahwa data memiliki perbedaan yang bermakna antar kelompok $(\mathrm{p}<0,05)$. Untuk mengetahui kelompok mana yang menunjukkan perbedan bermakna maka dilanjutkan dengan pengujian Post Hoc test.

Berdasarkan pengujian Post Hoc test dengan metode LSD menunjukkan bahwa kelompok kontrol negatif tidak memiliki perbedaan yang bermakna dengan kelompok kontrol normal $(p>0,05)$. Hal tersebut mengindikasikan bahwa basis salep tidak memiliki efektivitas penyembuhan luka akut stadium II terbuka. Kelompok kontrol negatif memiliki perbedaan bermakna dengan kelompok perlakuan salep fase minyak ekstrak ikan gabus konsentrasi $20 \% \quad(p<0,05)$. Hal tersebut mengindikasikan bahwa salep fase minyak ekstrak ikan gabus dengan konsentrasi 20\% memiliki efektivitas penyembuhan luka akut stadium II terbuka.

Kelompok kontrol positif memiliki perbedaan bermakna dengan salep fase minyak ekstrak ikan gabus dengan konsentrasi 20\%. Hal tersebut mengindikasikan bahwa kelompok kontrol positif tidak memiliki efek penyembuhan luka akut stadium II terbuka yang lebih baik dibandingkan dengan kontrol perlakuan salep fase minyak ekstrak ikan gabus konsentrasi $20 \%$.

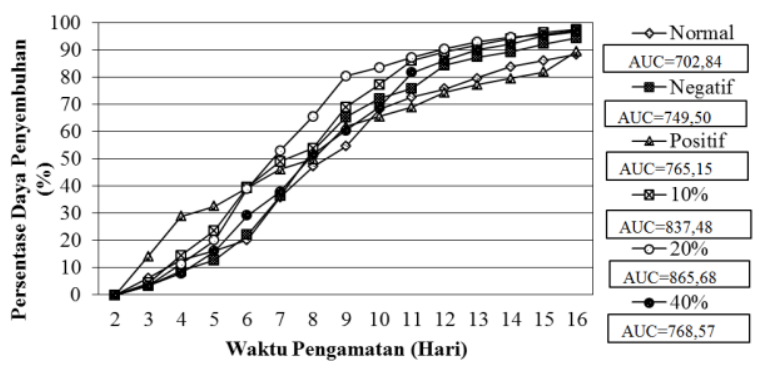

Gambar 3. Grafik Rata-rata Persentase Daya Penyembuhan Luka

Pemilihan basis salep yang tepat juga berpengaruh terhadap efektivitas penggunaan salep yang mengandung zat aktif sehingga diperoleh hasil penyembuhan yang optimal (Gambar 3). Penggunaan basis adeps lanae dan vaselin flavum karena sifat dari adeps lanae yang memiliki daya pelepasan obat yang tinggi dan merupakan lapisan penutup. Sedangkan sifat dari vaselin flavum sebagai penutup oklusif yang menghambat penguapan kelembaban secara normal dari kulit dan dapat memperpanjang waktu kontak sediaan pada kulit. Kedua basis tersebut sukar dicuci sehingga dapat meningkatkan absorpsi obat pada kulit (Ansel, 1989).

Sifat dari basis adeps lanae dan vaselin flavum yaitu dapat mempertahankan kelembaban pada daerah sekitar luka dapat mempercepat proses penyembuhan. Perawatan luka pada suasana lembab menyebabkan tubuh secara otomatis akan mempercepat terjadinya proses fibrinolisis oleh sel neutrofil dan sel endotel yang akan menghilangkan benang-benang fibrin secara cepat. Selanjutnya akan mempercepat pembentukan pembuluh darah baru di dalam luka dan pembentukan growth factor yang berperan 
dalam membentuk stratum corneum (Naibaho et al., 2013). Luka yang kering menyebabkan terbentuknya fibrin yang mengeras dan luka yang basah menyebabkan maserasi pada kulit (pelunakan) sehingga dapat merusak sekitar luka (Carville, 2012).

Penggunaan gel bioplacenton (kontrol positif) yang mengandung ekstrak plasenta $10 \%$ dan neomisin sulfat $0,5 \%$ menyebabkan luka menjadi kering sehingga terbentuk keropeng yang sukar lepas. Keropeng adalah bekuan darah yang mengering yang melindungi dermis dibawahnya. Keropeng yang kering pada luka akan menekan dan menghalangi suplai darah dan nutrisi serta memberikan barier untuk migrasi sitokin dengan epitelisasi yang lambat (Tarigan et al., 2017).

Secara teori, proses penyembuhan luka bisa berlangsung sampai berbulan-bulan bahkan bertahun-tahun. Namun, proses penyembuhan luka bisa berlangsung lebih cepat ataupun lebih lambat. Cepat atau lambatnya proses tersebut dipengaruhi oleh beberapa faktor, salah satunya nutrisi. Fase minyak ekstrak ikan gabus yang mengandung asam lemak tak jenuh omega-3 dan omega-6 merupakan nutrisi yang dapat mempercepat proses penyembuhan luka (Indonesia Enterostomal Therapy Nurse Association, 2014). Asam lemak omega-6 yang terdapat dalam minyak ikan adalah asam arakidonat yang merupakan substrat utama untuk sintesis eikosanoid yang memiliki efek pro dan antiinflamasi sehingga dapat mempercepat fase inflamasi. Enzim siklooksigenase membantu konversi asam arakidonat menjadi eikosanoid yaitu tromboksan dan prostasiklin yang berperan dalam menentukan kelancaran sirkulasi darah. Enzim lipoksigenase mengkonversi asam arakidonat menjadi leukotrien dan lipoxins yang berperan dalam fagositosis dan membersihkan sisa sel neutrofil (Collins and Sulewski, 2011; Astawan, 1998; Serhan, 2007; Monteiro, Ana, et al., 2011).

Asam lemak omega-3 khususnya EPA telah terbukti dapat membantu fibroblas dalam mensintesis kolagen. EPA berperan meningkatkan jumlah sitokin jenis IL-6 yang dapat meningkatkan produksi kolagen oleh fibroblas. Dengan meningkatnya jumlah kolagen maka proses penyembuhan luka juga akan berlangsung dengan cepat (Hankenson et al., 2000).

\section{KESIMPULAN}

Hasil uji statistik mengindikasikan bahwa salep fase minyak ekstrak ikan gabus (Channa striata) memiliki efektivitas penyembuhan luka akut stadium II terbuka pada tikus jantan galur wistar dibandingkan dengan kontrol negatif. Salep fase minyak ekstrak ikan gabus yang memberikan efektivitas penyembuhan luka terbaik yaitu salep dengan konsentrasi 20\% (Nilai AUC sebesar $865,683 \%$ hari dan \% daya penyembuhan sebesar $97,157 \%)$.

\section{UCAPAN TERIMA KASIH}

Penelitian ini merupakan bagian dari penelitian dosen dengan Dana Dipa Untan tahun 2015. Terima kasih kepada bapak Mohamad Andrie, M. Sc., Apt dan ibu Wintari Taurina, M. Sc., Apt.

\section{DAFTAR PUSTAKA}

Andrie, M. 2015. Formulasi Salep Ekstrak Ikan Gabus (Channa striata) dengan Variasi Konsentrasi Basis. Penelitian Dosen Dana DIPA, Pontianak, Universitas Tanjungpura.

Ansel, H.C. 1989. Pengantar Bentuk Sediaan Farmasi. $4^{\text {th }}$ ed (Penterjemah: Farida Ibrahim), UI Press, Jakarta, pp. 490-494.

Anton, T.J. 1989. Occupational Safety and Health Management, McGraw-Hill Book.Co, Singapore, pp. 118-121.

Astawan, M. 1998. Teknik ekstraksi dan pemanfaatan minyak ikan untuk kesehatan. Buletin Teknologi dan Industri Pangan, pp. 9:44-51.

Carville, K. 2012. Wound Care Manual. 6 ${ }^{\text {th }}$ ed, Silver Chain Foundation, Western Australia.

Collins, N., and Sulewski, C. 2011. Ostomy Wound Management, pp. 10-13.

Gadekar, R., Saurabh, M.K., Thakur, G.S., dan Saurabh, A. 2012. Studi of Formulation, Characterisation and Wound Healing Potential of Transdermal Patches of Curcumin. Asian J Pharm Clin Res, 5:225230.

Gitarja, W.S. 2008. Perawatan Luka Diabetes, Wocare, Bogor, Indonesia.

Gusdi, 0. 2012. Formulasi sediaan gel ekstrak ikan gabus (Channa Striata) sebagai obat luka sayat, Skripsi, Pontianak, Universitas Tanjungpura;.

Hankenson, K.D., Watkins, B.A., Schoenlein, I.A., Allen, K.G., Turek, J.J. 2000. Omega-3 fatty acids enhance ligament fibroblast collagen formation in association with changes in interleukin-6 production, Proc. Soc. Exp. Biol. Med, 223:88-95.

Indonesia Enterostomal Therapy Nurse Association (InETNA). 2004. Tim Perawatan Luka dan Stoma Rumah Sakit Dharmais. Perawatan luka, Makalah Mandiri, Jakarta, pp. 1-16.

Mansjoer, A. 2000. Kapita selekta kedokteran Edisi III, Media Aesculapius FKUI, Jakarta. 
Monteiro, Ana, P.T et al. 2011. Leukotriene $B_{4}$ Mediates Neutrophil Migration Induced by Heme. J Immunol, 186:6562-6567.

Morton, J.J.P., and Malone, M.H. 1992. Evaluation of Vulnerary by An Open Wound Procedure in Rats. Archieve Int Pharmacodyn, 196:117-128.

Naibaho, Yamlean, O.H., Wiyono, W. 2013. Pengaruh Basis Salep Terhadap Formulasi Sediaan Salep Ekstrak Daun Kemangi (Ocimum sanctum L.) pada Kulit Punggung Kelinci yang Dibuat Infeksi Staphylococcus aureus, Manado, Pharmacon Jurnal Ilmiah Farmasi, 2.

Naveh, H.R., Jafari, Taghavi, M.M., Shariati, M., Vazeirnejad, R., dan Rezvani, M.E. 2011. Both omega-3 and omega- 6 polyunsaturated fatty acids stimulate foot wound healing in chronic diabetic rat, Afr. J. Pharm. Pharmacol, 5:1713-1717.

Sabale, P., Bhimani, B., Prajapati, C., Sabale, V. 2012. An Overview of Medicinal Plants as Wound Healers, J App Pharm Sci, 2:143150.
Saleh, M., Hari, E.I., Delima, H.D., dan Siswoputranto, P.S. 1985. Standar tepung ikan di dalam pengembangan industri tepung ikan, Tim Analisa Komoditi Sekretariat Jenderal Departemen Pertanian, pp. 1-7.

Serhan, C.N. 2007. Resolution Phase of Inflammation: Novel Endogenous AntiInflammatory and Proresolving Lipid Mediators and Pathways. Annu. Rev. Immunol, 25:101-137.

Shafri, M.A., dan Mat, J.A.M. 2012. Therapeutic Potential of Haruan (Channa striatus): from food to medicinal uses, Mal. J. Nutr, 18:125136.

Sinambela, H.Y. 2012. Optimasi formulasi sediaan salep minyak ikan gabus (Channa Striata Bloch) sebagai obat luka sayat dengan metode simplex lattice design, Skripsi, Pontianak, Universitas Tanjungpura.

Tarigan, R., Pemila, U. 2007. Perawatan Luka: Moist Wound Healing. Makalah, Jakarta, Universitas Indonesia. 